\title{
CONTROL BY ANAF - MACROECONOMIC AND HARGHITA COUNTRY ANALYZES
}

\author{
Csaba BALINT ${ }^{1}$ \\ Monica TOADER \\ Adriana Ioana $C R O I T O R U$
}

\begin{abstract}
Starting with ANAF's "glory" period, that is in the Ciolos Government, each year, the Ministry of Public Finance boasts that it has collected more taxes and charges than was foreseen: for example in 2017 in November, it has already cashed as foreseen for the budget year 2017 (7\% over what was planned). These data are real, but with what price? ANAF has begun to verify the firms, and the present study examines macroeconomic data on the number of checks in the period 2014-2016, and for the same period we will also examine these data for Harghita County, where wages are almost the lowest in the whole country. Thus, it can be determined whether the macroeconomic trends are comparable to the Harghita County trends or not, and which will be the risk of being checked in Romania by ANAF - depending on where a company is registered.
\end{abstract}

Keywords: risk, control, macroeconomic trend

JEL Codes: H2

\section{Introduction}

Over the past 2-3 years, ANAF has "boasted" that it exceeded the amounts collected with a few percent of what was planned. These data are correct, but in most cases they are due to excessive controls by control bodies.

This paper aims at analyzing, at the macroeconomic level of Romania, the ANAF controls and the establishment of trends, and after these data to analyze these trends also in Harghita county, which is almost the poorest county in Romania ... from the point of wages and the number of companies.

\section{Own-challenge research}

\section{Methodology of research}

In general, we can state that the scientific research methodology gives the researcher, the doctoral candidate the chance to interpret as fairly as possible the economic events, the events that occur every day in the economic reality and are translated into forms, into accounting accounts.

In order to accomplish this research we used the following methods: study of references and bibliography, analysis of the legislation in force, collection and processing of information using tables, figures and diagrams in order to synthesize and highlight the results of the research.

In the second phase we collected data by quantitative methods, respectively from secondary sources. These secondary sources are the ANAF performance reports for each region, and where

${ }^{1} \mathrm{PhD}$ student, Univ. 1 December 1918, Alba Iulia, România

DOI: 10.29302/oeconomica.2018.20.1.4 
ANAF data was missing, we have added them from the sources of the National Trade Register Office (ONRC).

In relation to ANAF data, I have noticed a secretion that is not justified. Most of the data are public, however, when we contacted certain directors / directors at ANAF Harghita or Bucharest Region, we faced suspicions, not to mention the Ministry of Public Finance, where we met with a total and unjustified refusal.

The data used is collected from the reports of the 8 ANAF regions, very well hidden in ANAF's website, and the missing ones (eg. number of individuals) are extracted from the ONRC site. The obtained data were processed and presented in different diagrams, trying to achieve linear equations, but the data and the time series are very few (2015-2016), so we have not succeeded in including these time series in linear equations.

However, we have tried to look for correlations between economic phenomena translated into data without much success.

Calculations were performed using the MS Excel software.

\section{Limits of theoretical research}

This research has as a theme the identification of trends by the Romanian state in the verification of the companies at the national level, and at the microeconomic level (Harghita County), the verification of these trends, if they fit or not with the macroeconomic trends.

Regrettably, we have not found results from other research to resemble, or at least address these issues. There follows the identification of these themes ... if there is such a thing in the Romanian literature.

\section{Limits of empirical research}

The biggest problem is the lack of data from ANAF or the Ministry of Public Finance. As we have already mentioned, there is a secrecy within these structures - although there is a legal obligation to publish the data - which is not happening, or if some data are published, they are not consistent. The best example is the Ploiesti Region, where, besides mentioning amounts set for individuals under a control, there is no other precise data. After several questions, I received the unofficial answer that the person who drafted the activity report considered that individuals are also legal entities because they have fiscal code and are registered by the ONRC. (It is a very old problem: authorized individuals, individual businesses, family businesses - named as natural persons - are registered with the National Trade Register Office as commercial companies. Their code starts with $\mathbf{F}$ (physical) and not $\mathbf{J}$ (legal) However, in many places - eg. in banks, they are identified as legal entities and have the same internal rules as legal entities - respectively LLCs, SAs). Since the 2015 report was drawn up in this way, it is natural that it remained the same for 2016, no one has revised it. In other regions, I have not encountered these problems, but others appear, the lack of data for 2015, especially for individuals, or the drawing up of the VAT chapter.

With the same secrecy, we met at the Harghita Public Finance Administration. If we did not have personal knowledge, we could not get the data needed for this study.

\section{Analysis of data}

Because of the secrecy, we have data for Romania only for the years 2015-2016. However, for Harghita County we were able to obtain data for the years 2013-2016.

Data:

The fiscal vector for legal entities/individuals means how many legal entities/individuals are listed in the region for the years 2015/2016. 
Verified PJ/PF reflects the number of legal/physical entities controlled during that period.

Additional PJ/PF sums show the amount of additional amount set by tax inspectors for legal and physical persons. This amount includes capital (principal obligations), and late payment increases together with penalties (PF access obligations).

$P J / P F$ Fines - how many verbal processes are written for each control, and what is their sum?

\section{Results}

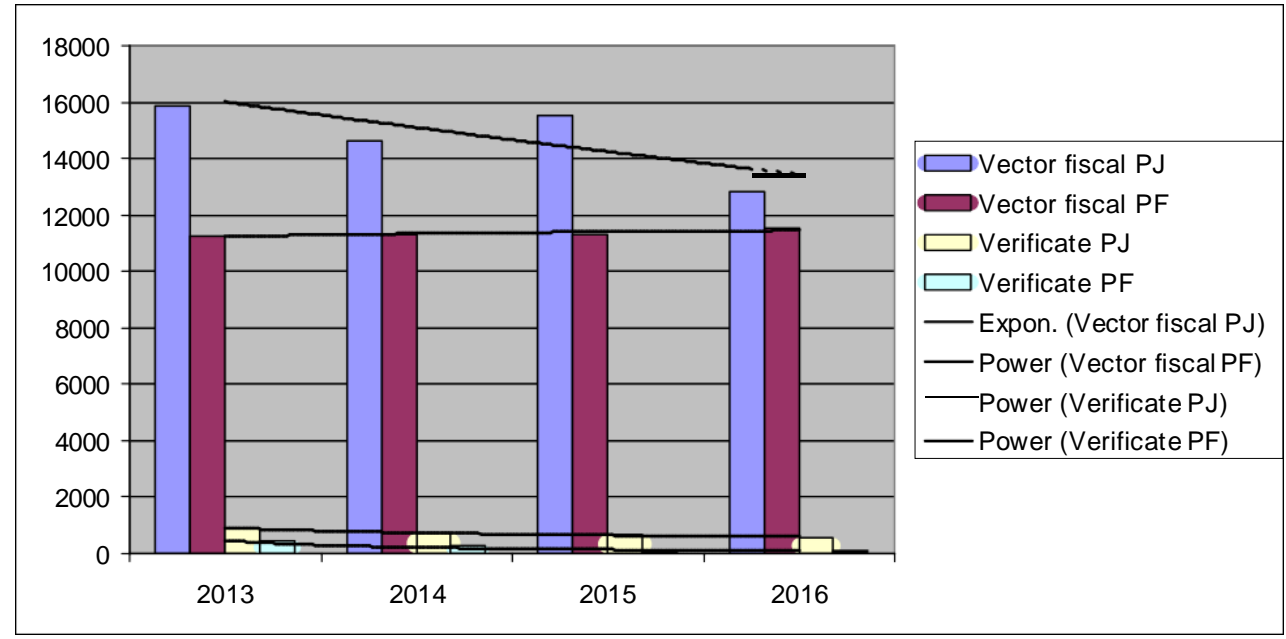

Chart 1

The chart shows that in the county of Harghita the number of individuals maintains a constant level, while the legal entities decrease.

The same trend is also observed in checks, constantly decreasing checks on both legal entities and individuals. (Chart 1)

At the national level, it is noticed (Chart 2) that the number of legal persons is increasing, and individuals are seeing an increase, but at a slower pace.

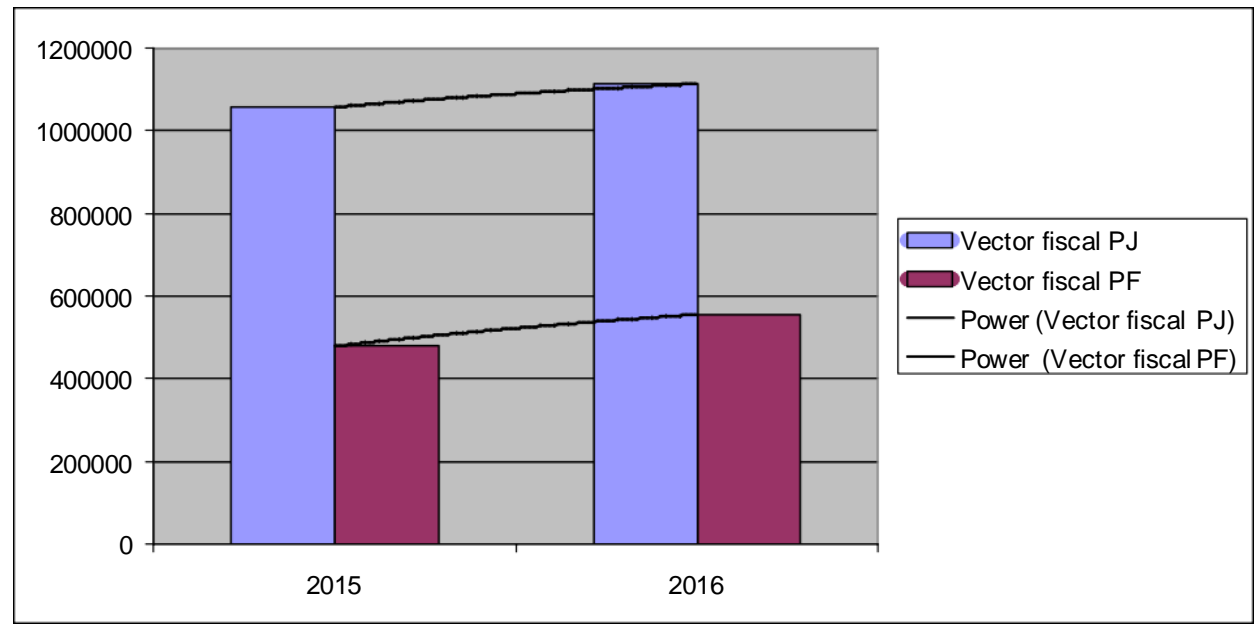

Chart 2

Interestingly, the number of legal checks drops, and individuals grow. (Chart 3). 


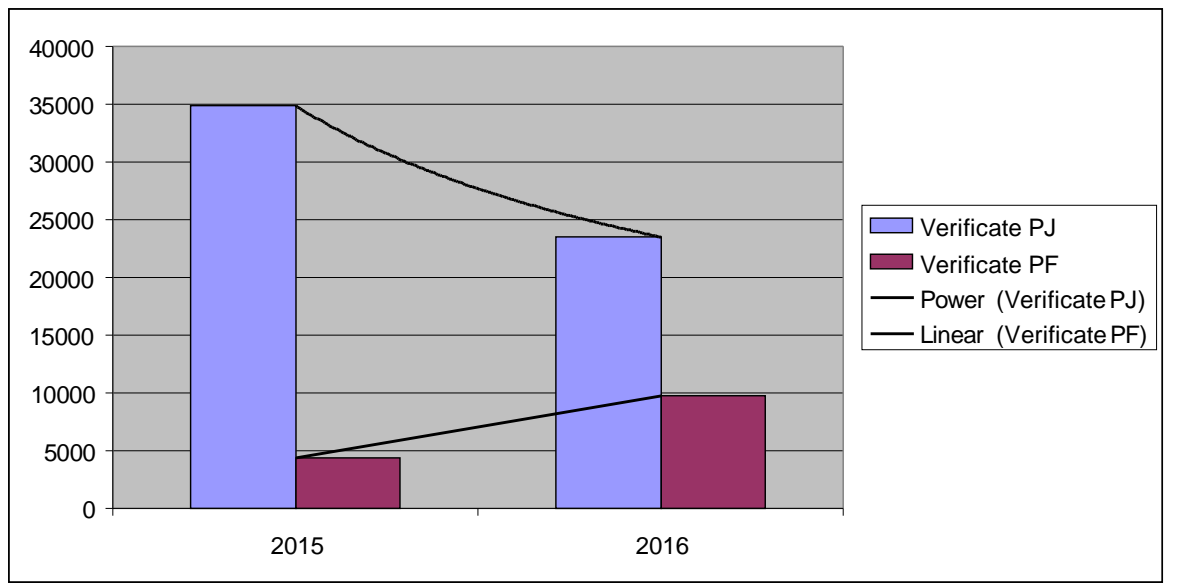

Chart 3

The additional amounts set by the control bodies are as follows:

At the national level, legal persons decrease and individuals grow. At the level of Harghita County, the trend is still decreasing in legal persons, while individuals keep up. (Chart 4 and Chart 5)

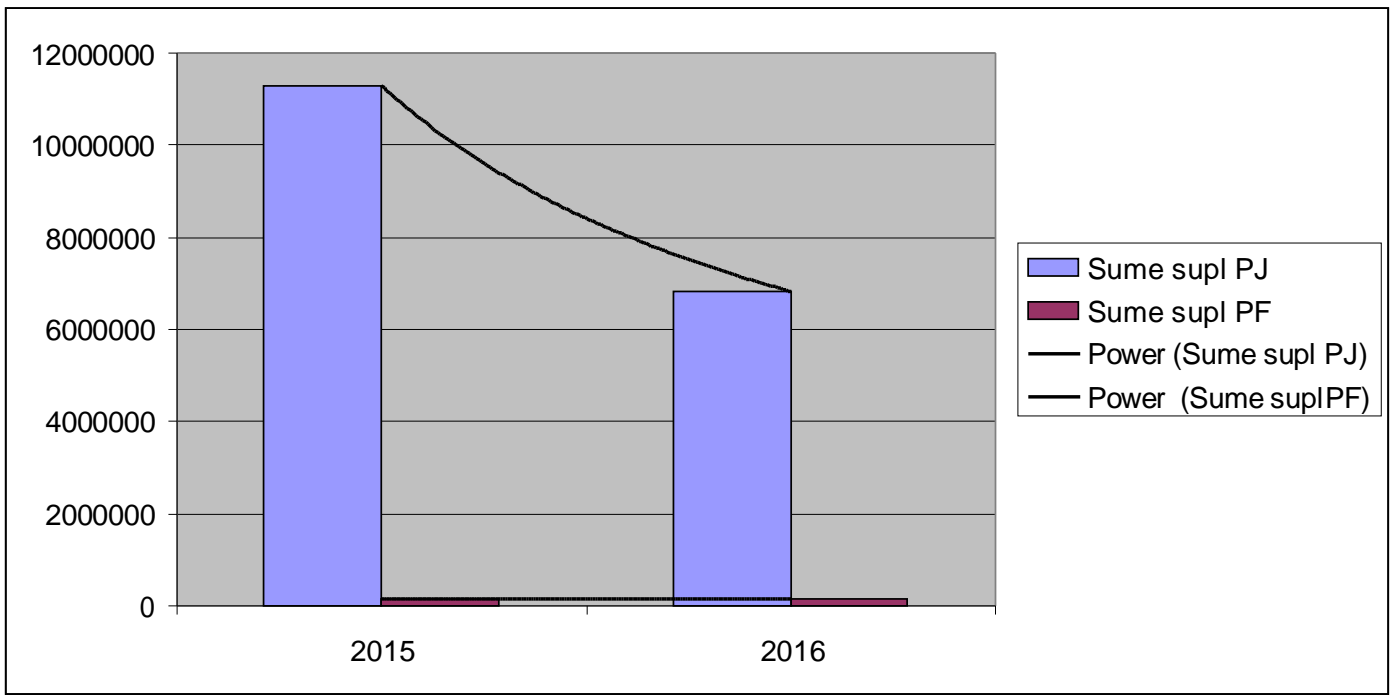

Chart 4 


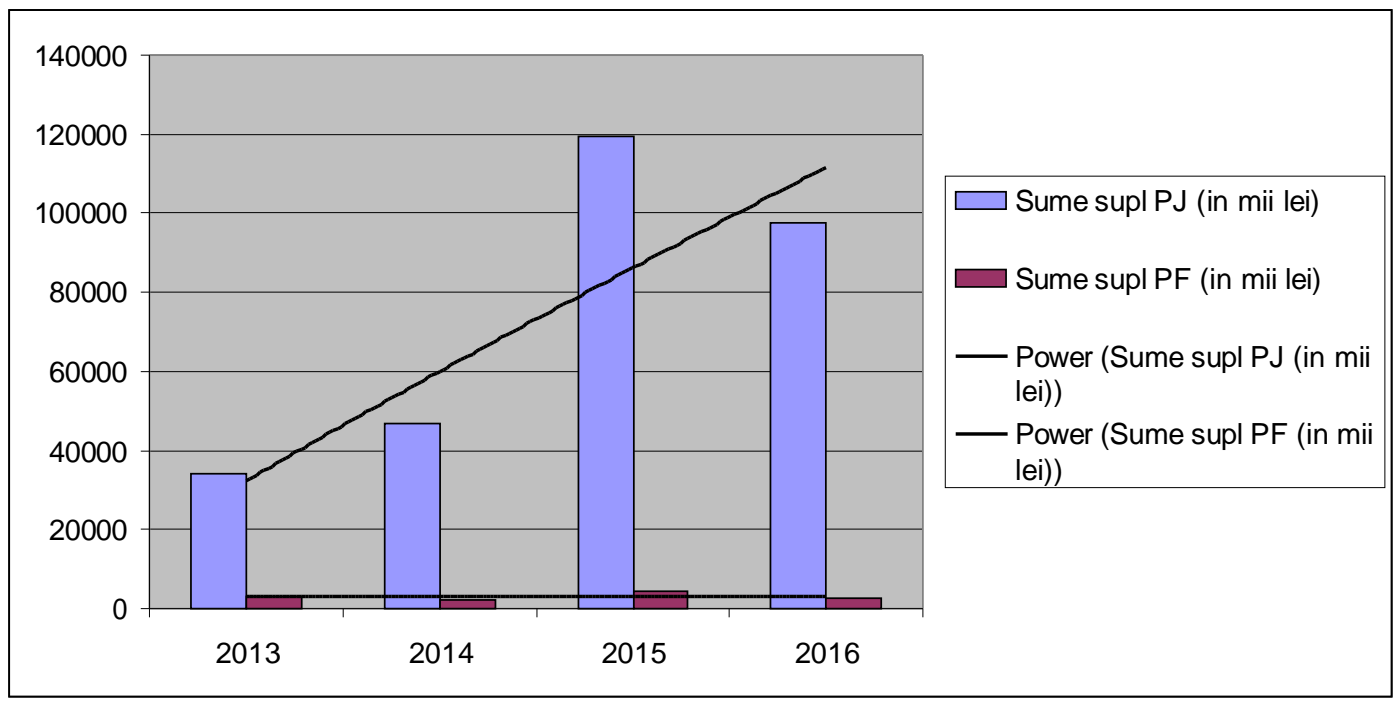

Chart 5

By calculating the likelihood of being controlled by ANAF, each region has another value, as shown in Chart 6.

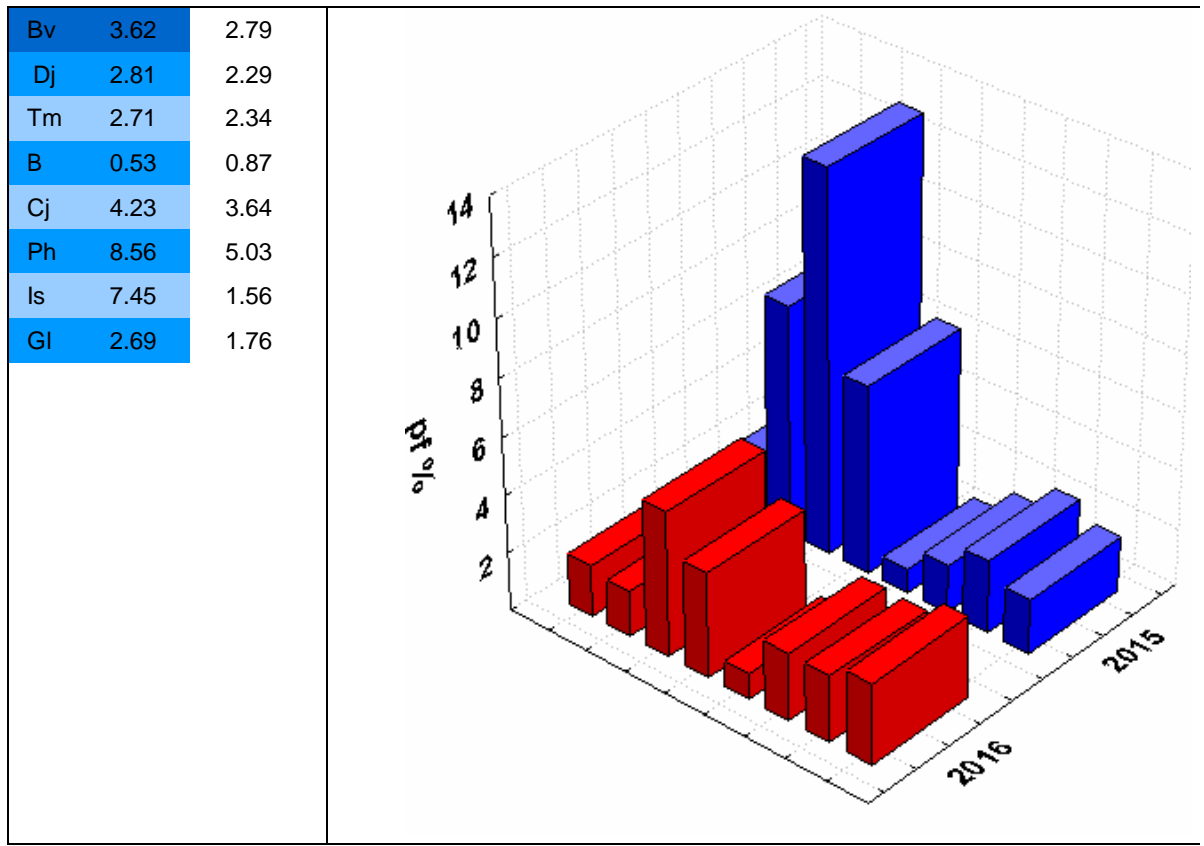

Chart 6

Thus, in the region of Brasov, in 2015 the probability was 3.62\%, and in 2016 it fell to $2.79 \%$. In the Bucharest region $0.53 \%$ in 2015, and in 2016 somewhat higher, $0.87 \%$. The highest probability in 2015 was in the Prahova Region - 8.56\% - and in 2015 also.

In Harghita County, according to Chart 7, the probability was about $5 \%$ for legal entities, and for natural persons falling from $3.93 \%$ to $0.97 \%$. 


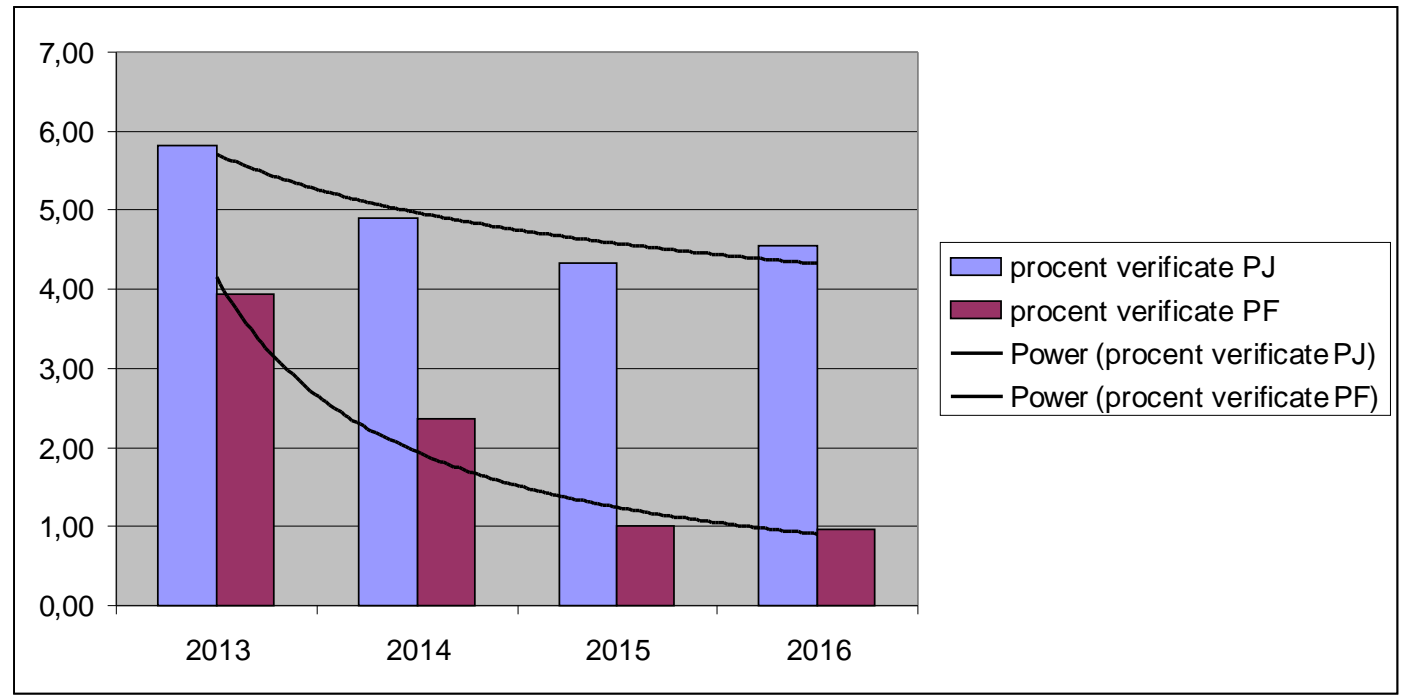

Chart 7

\section{Conclusions}

It can be determined that national results in Harghita County are not very oscilative, the same trend is found, especially if we observe the years 2015-2016. It is not true that in Harghita County, fiscal controllers are more demanding than in other parts of the country ... or at least could not demonstrate the existence of such a phenomenon.

Highlighted controls are fewer than previous years, probably because most of the controls are based on specialized software, and control agents will only come to the controlled controls when they receive the alert.

However, we can state that this part of the ANAF's control field must be worth exploring, because some aspects of control can be clarified, which newspapers - according to their usual habits inflate.

\section{Prospects for future research}

Without identifying all perspectives, we recommend the following directions for one or more research in the future:

- widening time series to at least 3 years so that empirical research can be performed based on statistics - and thus prescribing linear equations for an econometric model;

- finding appropriate sources from ANAF for wider and more accurate data.

\section{Bibliography}

1. Adelopo, I. Non-financial risc disclosure: The case of the UK-s Distressed banks. Australasian Accounting, Business and Finance Journal, 11 (2).

2. Albu N., Albu, N. 2012. Contabilitatea control și guvernanță, Editura Economică, București.

3. Amarfi-Railean, N. Abordarea managementului financiar contabil din perspectiva utilizării bazelor de date în „cloud”., Universitatea de Stat „Alecu Russo” din Bălți.

4. Amarfi-Railean, N. Diagnosticul financiar-contabil al întreprinderii în condițiile unui risc ridicat de insolvabilitate, Conferința Științifică Internațională, Asigurarea Valabilității Economico-Manageriale pt Dezvoltarea Durabilă a Economiei Regionale în Condițiile Integrării în UE. 
5. Bélyácz I. Várakozások, bizonytalanság, valószínüség. Közgazdasági Szemle: LX, iulie-august 2013, Budapesta

6. Bélyácz I.: Kockázat vagy bizonytalanság? Közgazdasági Szemle: LVII, iulie-august 2010, Budapesta.

7. Bernstein, Peter L. 2014. Împotriva zeilor, remarcabila poveste a riscului, Ed. Humanitas, București.

8. Biddle, G. C.; Kim, J. B.; Ma, L.; Song, F. M. 2011. Accounting conservatism and bankrupty risc, The 2011 Financial Accounting and Reporting Section Midyear Meeting by the American Accounting Association (AAA), Tampa, FL.

9. Bojian, O. 2003. Bazele contabilității Ed. Economică, București.

10. Bulat, I. ABC-ABM-Innovative Methods For Streamlining Public Spending, Fostering Knowledge Triangle in Moldova Conference Proceedings.

11. Callahan, G. 2007. Közgazdaságtan hús vér embereknek, Ed. Edge 2000, Budapesta.

12. Călin, O., Ristea, M. 2000. Bazele contabilității, pag. 51, Ed. Național, București.

13. Covlea M. 2008. Contabilitate, text de studio și aplicații, Ed. Pro Universitaria, București.

14. Daiman, S. 2011. Evoluția contabilității în perioada de tranziție a economiei românești, Disertație de doctorat, Univ. Babeș-Bolyai, Cluj Napoca.

15. Dobrotă, N. 1999. Dicţionar de economie, Ed. Economică, Bucureşti.

16. Ducu, C. M. 2013. Contribuții ale auditului intern la gestionarea riscurilor financiar-contabil, Disertație de doctorat, Univ. 1 Dec 1918, Alba Iulia.

17. Grunewald, I., 2012, Managementul riscului financiar - fundamente teoretice și aplicative, Universitatea Babeș-Bolyai, Cluj Napoca.

18. Günter, O: 2009. A Fuggerek, császári és királyi bankárok, Ed. Kelly Kiadó, Budapesta.

19. Horomnea, E. 2011. Dimensiuni științifice și sociale în cercetarea contabilă, Ed. Economică, București.

20. http://libweb.anglia.ac.uk/referencing/harvard.htm, download septembrie 2017.

21. http://www.perfect-service.ro/intelinet/2010/ianuarie/intel(i)net.php?legatura=4, download mai.2017.

22. http://www.ziare.com/jocuri/jocuri-online/piata-jocurilor-de-noroc-a-ajuns-la-1-miliarde-deeuro-romanii-joaca-50-100-de-lei-pe-luna-la-pacanele-1427717, download mai 2017.

23. https://dexonline.ro/definitie/cercetare, download mai.2017.

24. Istrate, C. 2016. Contabilitatea nu-i doar pentru contabili, Ed Evrika Publishing, București.

25. Jaksity Gy. A pénz természete, Ed. Alinea, Budapesta.

26. Kahneman, D. 2013. Gyors és lassú gondolkodás, Ed. HVG, Budapesta.

27. King, D. L., Case, C. J. 2003, The evolution of the United States Audit Report, Academy of 13. Accounting and Financial Studiues Journal.

28. Knight, F. H. 1921. Risc, Uncertainty and Profit, Boston MA.

29. Legea contabilității 82/1991, actualizată.

30. Macoviciuc, V., Boșca, L. C., Vreja, L. - coordonatori 2016. Etică și raționalitatea economică, Editura Ase, București.

31. Margaret, W., Dowd K., Humhrey, C. 2004. Credibility at risk? The accounting profession, risk reporting and the rise of VaR, CRIS Discussion Paper Series.

32. Noul Cod Civil.

33. Olimid, L. 1998. Măsurarea rezultatului contabil, Ed Economică, București.

34. OMFP 1802/2014.

35. Oprea, D. 1995. Premisele și consecințele informatizării contabilității, Ed Graphix, Iași.

36. Ordonanța de urgență nr.77 din 24 iunie 2009 privind organizarea și exploatarea jocurilor de noroc. 
37. Pântea, I. P. 1995. Contabilitatea Financiară a Agenților Economici din România, Ed. Intelcredo, Deva.

38. Pântea, I. P. 1999. Managementul Contabilității Românești, Ed. Intelcredo, Deva.

39. Pântea, I. P., Bodea G. 2007. Contabilitate Financiară Românească, Ed. Intelcredo, Deva.

40. Pop, A. 2000. Contabilitatea financiară aplicată în 2000, Ed Intelcredo, Deva.

41. Puiu, Ana Cornelia (Olteanu), 2012. Managementului Riscului Operațional, Academia de Studii Economice din Bucureşti.

42. Raport Antifraudă, http://www.antifrauda.ro/upload/files/brosura\%206\%20final\%20site.pdf, download mai 2017.

43. Raport performanță ANAF pentru anul 2015, https://static.anaf.ro/static/10/Anaf/Informatii_R/Raport_performanta_20042016.pdf, download iunie 2017.

44. Răboacă, D., Ciucur, D. 2004. Metologia cercetării științifice economice, Ed. Fundației România de Mâine, București.

45. Ristea, M., Dumitru, C. G. 2012. Libertate și conformitate în standardele reglementările contabile, Ed. Ceccar, București.

46. Sava, I. N. 2012. Societatea Riscului - Studii de securitate, Centrul Roman de Studii Regionale.

47. Sharp, H. et al. 1983. Tha Management of a Student Research Proiect, Aldeshot Hants, Gower.

48. Studiu Pwc Romania, http://incont.stirileprotv.ro/idei-de-afaceri/cati-bani-aduc-la-bugetul-destat-jocurile-de-noroc-si-pariurile.html.

49. Sunder, S. 2015. Risc In Accounting, A Journal of Accounting, Finance, and Business Studies, Vol. 51, No. 4.

50. Teoria riscurilor și aplicații nr. 1/2011, Ed. Alexandru Myller, Iași.

51. Todea, N., Dorin, I., Anca, U. 2011. Calitatea Informației Contabile, suport al deciziei manageriale, Analele Universității Constantin Brâncuși din Tg. Jiu, Seria Economie, Nr. 3.

52. Ultimele precizări legate de controalele ANAF la operatorii din industria jocurilor de noroc, https://www.facebook.com/notes/agen\%C8\%9Bia-na\%C8\%9Bional\%C4\%83-de-administrarefiscal $\% \mathrm{C} 4 \% 83 /$ ultimele-preciz $\% \mathrm{C} 4 \% 83$ ri-legate-de-controalele-anaf-la-operatorii-dinindustria-jocuri/1527963194189662/, download mai 2017.

53. www.onrc.ro, download august 2017.

54. www.rombet.com, download iunie 2017. 